\title{
A RELAÇÃO ENTRE AS MÁXIMAS DE DIÓGENES DE ENOANDA E A FILOSOFIA DE EPICURO
}

\author{
Rogério Lopes dos Santos ${ }^{1}$
}

\section{Resumo:}

O presente artigo tem como objetivo apresentar a relação entre as máximas de Diógenes de Enoanda e o que temos de genuinamente epicureu, ou seja, com o material (cartas, máximas e fragmentos) admitido como de autoria incontestável de Epicuro. Com essa apresentação, nós evidenciamos a força da ortodoxia da doutrina de Epicuro, pois, de um modo geral não existem divergências entre o que Epicuro ensinava em Atenas no século III a.C. e o que Diógenes de Enoanda afirmava ser o Epicurismo no século II d.C. Na verdade, há uma única máxima que parece não seguir a doutrina de Epicuro (Diog. Oen. 107). Entretanto, essa divergência é justificada pelo fato de que essa máxima está fragmentada. Nesse sentido, acreditamos que o presente artigo consiste em uma contribuição positiva para a comunidade acadêmica que se dedica ao estudo do Epicurismo, ainda mais se considerarmos o fato de que se trata de um epicureu sobre o qual temos poucos artigos, sobretudo no Brasil. Para a realização desse trabalho, nos servimos aqui das seguintes obras: (i) El sabio camino hacia la felicidad: Diógenes de Enoanda y el gran mural epicúreo, de Carlos García Gual (2016), da qual retiramos as máximas de Diógenes de Enoanda; (ii) a Carta a Heródoto, Carta a Pítocles, Carta a Meneceu, bem como as Máximas Principais e as Sentenças Vaticanas, de Epicuro; (iii) o Livro X da obra Vidas e Doutrinas dos Filósofos Ilustres, do doxógrafo grego Diógenes Laércio.

Palavras-chave: Diógenes de Enoanda. Epicuro. Epicurismo. Ética.

\section{THE RELATION BETWEEN DIOGENES OF OINOANDA MAXIMS AND THE PHILOSOPHY OF EPICURUS}

\begin{abstract}
:
This article aims to present the relation between Diogenes of Oinoanda maxims and what we have as genuinely epicurean, i.e, with the material (letters, maxims and fragments) admitted as undisputed authorship of Epicurus. With this presentation, we show the strength of the orthodoxy Epicurus's doctrine, because generally speaking there are no differences between what Epicurus taught in Athens in the 3rd century BC and what Diogenes of Oinoanda claimed to be Epicureanism in the 2nd century AD. In fact, there is a single maxim that does not seem to follow Epicurus's doctrine (Diog. Oen. 107). However, this divergence is justified by the fact that this maxim is fragmented. Thus we believe that this article is a positive contribution to the academic community dedicated to the study of Epicureanism, especially considering the fact that it is an epicurean about which we have few articles, especially in Brazil. For the accomplishment of this work we use here the following books: (i) El sabio camino hacia la felicidad: Diógenes de Enoanda y el gran mural epicúreo, of Carlos García Gual (2016), from which we take the Diogenes of Oinoanda maxims; (ii) the Epistula ad Herodotum, Epistula ad Pythoclem, Epistula ad Menoeceum, as well as the Ratae Sententiae and the Vatican Sayings, of Epicurus; (iii) the Book X from Lives of Eminent Philosophers of the greek doxographer Diogenes Laertius.
\end{abstract}

Keywords: Diogenes of Oinoanda. Epicurus. Epicureanism. Ethic.

\section{Sobre Diógenes de Enoanda e as máximas contidas em seu muro}

Diógenes (séc. II d.C.) surge na História da Filosofia como o responsável pela construção de um grande muro na antiga cidade de Enoanda (região da Turquia). Nesse muro, Diógenes encomendou a inscrição de alguns ensinamentos da Filosofia de Epicuro (341 a.C. -

1 Graduado em Filosofia (Licenciatura) pela Universidade Estadual de Maringá (UEM). Mestre e doutor em Filosofia pela Universidade Federal de Santa Maria. E-mail: rogeriolopes06@hotmail.com. 
270 a.C.). Dos ensinamentos que sobreviveram ao tempo e à ação humana, temos: (i) fragmentos relativos à Física (physiologia) e à Ética epicurea; (ii) duas cartas de Diógenes, sendo uma delas endereçada ao seu amigo Antípatro, e a outra a Dionísio e a Caro; (iii) uma breve seleção de máximas (objeto de análise do presente estudo); (iv) uma mensagem de Diógenes para a sua família e amigos; (v) uma carta de Diógenes para a sua mãe; (vi) e, por fim, um epítome sobre a velhice.

De acordo com Gual, as pedras que formavam 'o muro de Diógenes' “[...] foram utilizadas em outras construções da região [de Enoanda] sem nenhum receio nem reparo cultural, como meros blocos mudos" (GUAL, 2016, p. 8, tradução nossa). Tais pedras permaneceram assim até o final do século XIX, mais especificamente até o ano de 1889 - ano em que foram analisadas pelo epigrafista francês George Cousin. Sobre Cousin, Mireia Movellán Luis (2016), em seu capítulo na obra de Gual que aqui analisamos, faz as seguintes observações:

[...] George Cousin, começou a prestar atenção e descobriu um nome, Diógenes, no que parecia ser algo assim como o equivalente, em epigrafia, ao que hoje seria o título e dedicatória de um livro. Esse nome, e o bloco que o continha, parecia dar coerência aos 64 fragmentos circundantes que então começaram a fazer sentido: resultaram pertencer a uma grande inscrição colocada em um pórtico, com certeza na ágora da cidade, como um anúncio do evangelho de Epicuro (GUAL, 2016, p. 16, tradução nossa).

Embora Cousin seja de grande importância para a história de reconstrução do conteúdo do muro de Diógenes, o trabalho de outros tantos pesquisadores, foi imprescindível para a divulgação e para o aprimoramento na ordenação de tal conteúdo. Tais pesquisadores são (seguindo a exposição de Mireia M. Luis): Maurice Holleaux, Pierre Paris, Hermann Usener, Rudolf Heberdey, Ernst Kalinka, Johann William (responsável pela primeira edição Teubner, em 1907), Grilli (com sua edição em italiano), C. W. Chilton (responsável pela segunda edição Teubner, em 1963) e Martin Ferguson Smith, com sua edição crítica publicada em 1993 - obra de referência até os dias atuais, e que é constantemente complementada através de artigos produzidos por Jürgen Hammerstaedt e pelo próprio Smith (GUAL, 2016, p. 24-25).

Em sua obra El sabio camino hacia la felicidad: Diógenes de Enoanda y el gran mural epicúreo, Gual reproduz tanto os fragmentos contidos na obra de Smith de 1993, quanto os fragmentos publicados posteriormente (nos anos de 2008, 2009, 2010...), os quais

\begin{tabular}{|l|l|l|l|l|}
\hline Q Povista Dialectus & Ano 9 & n. 16 & Janeiro-Abril 2020 & p. $11-37$ \\
\hline
\end{tabular}


são indicados com a sigla NF: Nuevos fragmentos. Dos fragmentos reproduzidos na obra de Gual, temos um total de dezoito máximas. Com relação especificamente às máximas, cabe ressaltar a diversidade do seu conteúdo: nelas podemos encontrar não apenas as discussões epicureas relativas aos fenômenos naturais (Diog. Oen. 98. 99), mas também o embate teórico de Epicuro com a Filosofia de Platão (Diog. Oen. NF 155). No entanto, o tema central das máximas de Diógenes é a Ética. Das dezoito máximas das quais dispomos, apenas três delas (Diog. Oen. 98. 99. NF 155) não operam no âmbito da Ética de Epicuro. Isso nos leva a conjecturar que, embora Diógenes fosse conhecedor do Cânon e da Física (physiologia) de Epicuro, ${ }^{2}$ o seu real objetivo era trabalhar em prol da divulgação da Ética epicurea. ${ }^{3}$

A análise que se segue tem como objetivo evidenciar de que forma as máximas de Diógenes de Enoanda se relacionam com os textos de Epicuro, mais especificamente com: a Carta a Heródoto; a Carta a Pítocles; a Carta a Meneceu; as Máximas Principais (tàs kyrías autou dóxas) ${ }^{4}$ e as Sentenças Vaticanas (Gnomologium Vaticanum). Nesse sentido, procederemos de modo a identificar em qual discussão feita por Epicuro as máximas de Diógenes se encaixam, bem como se há alguma dessas máximas que não esteja alinhada à doutrina de Epicuro. Acreditamos que esse tipo de análise contribui para que possamos visualizar em que medida as novas descobertas em torno da Filosofia epicurea nos ajudam a compreender essa corrente filosófica. Dito isso, passemos, então, à análise das máximas do epicureu Diógenes de Enoanda.

\section{Análise das máximas de Diógenes e a sua relação com os textos canônicos de Epicuro}

Sobre a divisão da Filosofia epicurea, conferir: (D.L. X. 29-30).

'Conjecturamos' tendo em vista que o conteúdo do 'muro de Diógenes' ainda não foi completamente descoberto e analisado.

4 Sobre a tradução Máximas Principais, cabe as seguintes considerações feitas por Miguel Spinelli (2009) em Os Caminhos de Epicuro: "Kýrios designa o que tem autoridade, o senhorio, o soberano, hê kýria o poder, a autoridade, a supremacia, o primado, e dóxa a opinião, o parecer, a ponderação... Há diversidade nas traduções brasileiras de Kýriai dóxai; na de Mário da Gama Kury - Diógenes Laércio, Vidas e doutrinas dos filósofos ilustres - foi traduzida por Máximas principais; Reinholdo Ullmann - Epicuro: o filósofo da alegria - traduziu por Sentenças ou Máximas principais, mas acabou optando apenas por Sentenças principais. João Quartim de Moraes - Epicuro: as luzes da ética - refere-se de três maneiras: por Principais sentenças, por Máximas principais e por Máximas fundamentais. Não dá para dizer que há uma unanimidade, no entanto todos tendem a se referir às tàs kýriais autoû dóxas pôr as Máximas principais de Epicuro, o que por si só já começa a se constituir numa "tradição"." (SPINELLI, 2009, p. 174).

\begin{tabular}{|l|c|c|c|c|}
\hline Revista Dialectus & Ano 9 & n. 16 & Janeiro - Abril 2020 & p. $11-37$ \\
\hline
\end{tabular}


Todos os seres humanos podem se salvar por si mesmos, auxiliados por nós, e conseguir apagar por completo seus infortúnios anímicos e superar os sofrimentos da angústia e dos medos (Diog. Oen. 97, tradução nossa).

A ideia de que "Todos os seres humanos podem se salvar por si mesmos [...]" revela a tese epicurea de que a felicidade (a 'salvação' dos "infortúnios anímicos”, a superação dos "sofrimentos da angústia" e "dos medos") não se encontra em nenhum outro lugar (na religião, por exemplo), senão dentro do próprio humano individualmente considerado. Trata-se da autárkeia, ou autossuficiência, defendida por Epicuro, e que Spinelli esclarece ao fazer a seguinte afirmação:

O princípio epicurista básico da autárkeia supõe que a Natureza - em particular a natureza íntima do humano - muniu a todos do necessário quer para o viver prazeroso, quer para a fuga dos sofrimentos ou dos males da vida. A Natureza nos dotou da capacidade de cuidar de nós mesmos como se fôssemos verdadeiros deuses gerenciadores da nossa própria vida (SPINELLI, 2009, p. 84).

Sobre a afirmação de Diógenes segundo a qual os seres humanos são capazes de se salvar por si mesmos, porém, “[...] auxiliados por nós [...]”, vale esclarecer que a referência é à doutrina de Epicuro. Assim, temos: embora a doutrina epicurea ofereça os mecanismos a partir dos quais os seres humanos podem alcançar a sua 'salvação', a atitude (o esforço) em prol desse objetivo é de inteira responsabilidade daquele que deseja ser 'salvo'.

\section{II}

O raio é produzido por uma violenta erupção das nuvens ao rasgá-las o vento e um fogo compacto. O terremoto (nasce) de uma violenta pressão dos ventos no interior da Terra e por outras causas (Diog. Oen. 98, tradução nossa).

Alinhada a essa máxima, temos ainda uma terceira, da qual se segue este ensinamento:

\section{III}

Não é de se estranhar que o granizo esteja presente no meio da estação do verão. Porque há neve que não se vê, mas que persiste em camadas muito finas e que podem causar o granizo. Da mesma forma, também existe ar gelado nas áreas muito altas do céu (Diog. Oen. 99, tradução nossa).

A discussão na qual as máximas II e III estão inseridas gira em torno da Física epicurea, e aqui cabem três considerações. A primeira se refere à relação de convergência

\begin{tabular}{|l|l|l|l|l|}
\hline Q Povista Dialectus & Ano 9 & n. 16 & Janeiro-Abril 2020 & p. $11-37$ \\
\hline
\end{tabular}


dessas máximas com o que Epicuro afirma em sua Carta a Pítocles. Nesse sentido, basta conferir os seguintes pontos: (i) sobre como se formam os raios (Epicur. Ep. Pyth. 103); (ii) como surgem os terremotos (Epicur. Ep. Pyth. 105); (iii) como se formam a neve e o granizo (Epicur. Ep. Pyth. 106-108).

A segunda consideração que propomos é feita à luz do que conjecturamos anteriormente, a saber, de que, por meio das máximas, Diógenes tinha por principal objetivo a divulgação da Ética epicurea, e não o conhecimento específico das confabulações de Epicuro sobre a Natureza. Afirmamos isso não só pelo fato de que, no muro de Diógenes, o número de máximas relativas à Ética é maior do que aquelas relativas à Física, mas também pelo fato de que, para o próprio Epicuro, só há sentido na investigação da Natureza visto a sua intrínseca relação com a Ética - o que justificaria no muro de Diógenes a presença das máximas relativas à Física epicurea entre as máximas relativas à Ética epicurea. Acerca dessa pretendida relação entre as investigações sobre a Natureza e a Ética, Epicuro faz os seguintes

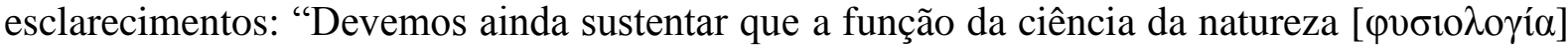
é a determinação precisa da causa dos elementos principais e que nesse conhecimento consiste a felicidade [...]" (Epicur. Ep. Hdt. 78, grifo nosso). Daí também a afirmação de Epicuro, segundo a qual:

Em primeiro lugar lembra-te de que, como tudo o mais, o conhecimento dos fenômenos celestes, quer os consideremos em suas relações recíprocas, quer isoladamente, não têm outra finalidade além de assegurar a paz de espírito

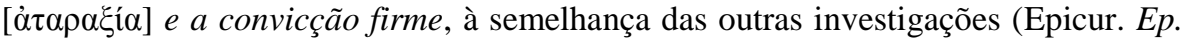
Pyth. 85, grifo nosso).

Por "paz de espírito" o leitor deve entender o estado de ataraxia: um estado de ausência de perturbações físicas e psíquicas, o qual é assumido por Epicuro como fim (télos) humano e a máxima expressão de prazer (Epicur. Ep. Men. 131). Ou seja, o estudo dos fenômenos celestes só se justifica em razão do seu valor acautelatório: investiga-se a Natureza a fim de se desvencilhar dos mitos (da ideia de que há um deus irado que fulmina animais e casas com o seu raio, ou faz cair gelo do céu, mesmo durante o verão, no intuito de prejudicar a plantação de alguém que lhe insultou de alguma forma) e, dessa forma, conquistar a felicidade.

Por fim, a terceira consideração pertinente às máximas de Diógenes relativas à Física de Epicuro é: elas consistem em apenas um modo (de vários possíveis) para se explicar

\begin{tabular}{|l|l|l|l|l|}
\hline Q Rovista Dialectus & Ano 9 & n. 16 & Janeiro-Abril 2020 & p. $11-37$ \\
\hline
\end{tabular}


os fenômenos aos quais elas se referem. Trata-se do critério de análise epicureu relativo, tanto aos fenômenos como o movimento dos astros e os eclipses, quanto aos fenômenos do tipo enunciado pelas máximas de Diógenes (os raios; os terremotos; as geadas; a neve). Esse critério consiste na admissão de causas múltiplas para os fenômenos naturais, desde que observada certa plausibilidade na explicação do fenômeno analisado (Epicur. Ep. Pyth. 87). Um bom exemplo nesse sentido está nas reflexões de Epicuro acerca do sol e da lua:

Os giros do sol e da lua devem-se possivelmente à posição oblíqua do céu, constrangido a estar nessa posição em certas épocas, mas também podem ser devidos à pressão contrária do ar, ou ainda ao fato de a matéria sempre adequada se incendiar continuamente e depois tornar-se rarefeita, ou enfim ao fato de desde a origem tal movimento vorticoso ter estado intimamente ligado a esses astros, de maneira a realizar-se como numa espiral (Epicur. Ep. Pyth. 93, grifo nosso).

Na Filosofia epicurea, a admissão de causas múltiplas para os fenômenos naturais tem o objetivo de tranquilizar a mente humana, sobretudo daqueles que detêm pouco ou nenhum saber. Isso porque, ao apontar para a possibilidade de se explicar os fenômenos naturais de várias formas plausíveis sem recorrer ao mito, Epicuro acreditava desfazer o medo daqueles que, alimentados pelos mitos da religião, mas carentes da Filosofia, atribuíam aos deuses a responsabilidade de tudo o que se passa na Natureza (o surgir dos eclipses; as chuvas em excesso; os terremotos, etc.).

\section{IV}

Platão fez bem ao reconhecer que o universo teria uma origem, mas não ao supor um criador, sem admitir a natureza como a criadora, e mal ao chamá-lo de eterno (Diog. Oen. $N F 155$, tradução nossa) ${ }^{5}$

Tal como nas máximas II e III, temos aqui a Física epicurea como centro da discussão, mais precisamente a divergência da mentalidade epicurea com os pressupostos de Platão relativos à origem cosmos (kósmos). De fato, Diógenes tinha motivos para afirmar tal divergência, dado que, quando consideramos as duas Filosofias (a de Epicuro e a de Platão)

5 Smith e Hammerstaedt (2008) traduziram esse fragmento da seguinte forma: "Although Plato was right to acknowledge that the world had an origin, even if he was not right to introduce a divine craftsman of it, instead of employing nature as its craftsman, he was wrong to say that it is imperishable" (SMITH \& HAMMERSTAEDT, 2008, p. 25).

\begin{tabular}{|l|l|l|l|l|}
\hline Q Povista Dialectus & Ano 9 & n. 16 & Janeiro - Abril 2020 & p. $11-37$ \\
\hline
\end{tabular}


no tocante à formação do cosmos, não há pontos de contato. ${ }^{6}$ Acerca dessa máxima de Diógenes, as seguintes considerações de Smith e Hammerstaedt são fundamentais:

\begin{abstract}
Para os epicuristas, nosso mundo, como cada um dos infinitos mundos no universo infinito, é uma estrutura temporária, formada por um processo puramente natural, quando uma grande quantidade de átomos complementares se reúne em uma grande área do vazio. Além de ter um começo, terá um fim, que ocorrerá quando forças internas ou externas fizerem com que seja dissolvido em seus átomos componentes. A visão de Platão era muito diferente. Como Epicuro, ele acreditava que o mundo tinha um começo - uma crença pela qual Diógenes o elogia. Mas esse foi o único ponto importante sobre o qual os dois filósofos concordaram. Platão descreve no

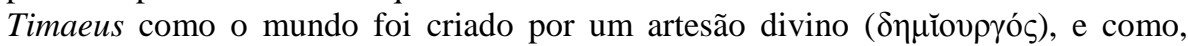
apesar de material, durará o tempo que Deus quiser, o que, como Deus não destruirá sua boa criação, significa que durará para sempre (SMITH \& HAMMERSTAEDT, 2008 , p. 25 , tradução nossa). ${ }^{7}$
\end{abstract}

Eis o raciocínio apresentado no Timeu acerca da eternidade do mundo a que se referem Smith e Hammerstaedt:

\begin{abstract}
Mas ainda quanto ao mundo, temos que apurar o seguinte: aquele que o fabricou produziu-o a partir de qual dos dois arquétipos: daquele que é imutável e inalterável ou do que devém. Ora, se o mundo é belo e o demiurgo é bom, é evidente que pôs os olhos no que é eterno; se fosse ao contrário - o que nem é correto supor -, teria posto os olhos no que devém. Portanto, é evidente para todos que pôs os olhos no que é eterno, pois o mundo é a mais bela das coisas devenientes e o demiurgo é a mais perfeita das causas. Deste modo, o que deveio foi fabricado pelo demiurgo que pôs os olhos no que é imutável e apreensível pela razão e pelo pensamento ( $\mathrm{Pl}$. Ti. 28C-29A).
\end{abstract}

Sobre as considerações de Smith e Hammerstaedt sobre a physiologia de Epicuro, cabem os seguintes esclarecimentos. Comecemos, pois, pela sua admissão dos átomos como o

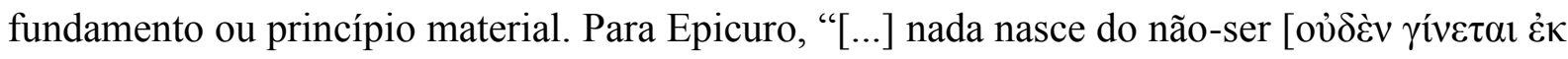

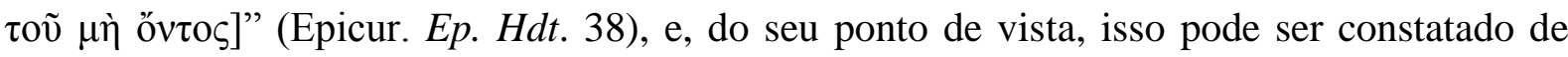
duas formas: (i) "Se não fosse assim, tudo nasceria de tudo e nada teria necessidade de seu próprio germe" (Epicur. Ep. Hdt. 38); (ii) "Se aquilo que desaparece perecesse e se resolvesse no não-ser, todas as coisas estariam mortas, pois não existiriam aquilo em que deveriam resolver-se" (Epicur. Ep. Hdt. 39). O "germe", ou seja, aquilo que resta intacto na aparente

6 Isso torna o artigo What did Epicurus Learn from Plato? (2017), de Lenn E. Goodman e Scott Aikin, ainda mais interessante, uma vez que o esforço desse estudo é feito justamente no sentido de apontar para a presença da Filosofia de Platão na Filosofia de Epicuro nos mais diversos âmbitos. Cf.: https://doi.org/10.1017/S0031819117000110.

7 O discurso de Timeu, o qual nos é apresentado como "[...] o mais entendido em astronomia e o que mais se empenhou em conhecer a natureza do mundo [kósmos] [...]" (Pl. Ti. 27A), inicia-se no passo 27C desse Diálogo.

\begin{tabular}{|l|l|l|l|l|}
\hline Q Rovista Dialectus & Ano 9 & n. 16 & Janeiro-Abril 2020 & p. $11-37$ \\
\hline
\end{tabular}


dissolução dos corpos compostos (por exemplo, da morte do ser humano ou dos animais) é o átomo, indivisível, imutável e impenetrável (Epicur. Ep. Hdt. 41).

Para além de indivisível, imutável e impenetrável, Epicuro concebeu outras duas importantes características estruturais para os átomos, a saber, peso (báros) (Epicur. Ep. Hdt. 61) e infinitas formas (schêmata) (Epicur. Ep. Hdt. 42). A infinidade relativa ao formato dos átomos é admitida por Epicuro em razão deste raciocínio: “[...] não seria possível que a variedade ilimitada dos fenômenos derivasse do número limitado das mesmas figuras" (Epicur. Ep. Hdt. 42). Com relação ao peso, essa característica é admitida tendo em vista que, para Epicuro, é ela a causa do movimento dos átomos pelo vazio. ${ }^{8}$ Nas palavras de Cícero (106 a.C. -43 a.C.):

Ele [Epicuro] acredita que esses mesmos corpos sólidos indivisíveis são levados pelo seu próprio peso perpendicularmente para baixo, o qual considera o movimento natural de todos os corpos [...] (Cic. Fin. I. 6. 18, tradução nossa).

Sobre essa afirmação de Cícero, cabe aqui a seguinte correção: de fato, para Epicuro, é o peso a causa do movimento dos átomos, porém, tal movimento não se dá necessariamente "para baixo". Isso porque, “[...] o todo é infinito [...]” (Epicur. Ep. Hdt. 41), ou seja, não tem delimitações, de modo que 'alto' e 'baixo' não podem ser considerados em absoluto o ponto 'mais alto' ou o ponto 'mais baixo' (Epicur. Ep. Hdt. 60). Nesse sentido, por natureza, os átomos se dirigem para todas as direções e, consequentemente, eles acabam por colidir uns com os outros. Como resultado dessa colisão, os átomos podem: (i) se repelir e, dessa forma, se dirigir para direções opostas; (ii) se agregar, formando assim os corpos compostos (os astros, planetas, etc.). ${ }^{9}$ Daí a afirmação de Smith e Hammerstaedt de que:

Para os epicuristas, nosso mundo, como cada um dos infinitos mundos no universo infinito, é uma estrutura temporária, formada por um processo puramente natural,

8 Esse é um ponto de divergência fundamental entre Epicuro e Demócrito de Abdera (460 a.C. - 370 a.C.), e sobre ela cabem as seguintes considerações de Margherita Isnardi Parente (1974): "Para Epicuro, o peso dos átomos tem um papel fundamental no seu movimento, enquanto que, para Demócrito, o peso tem um valor muito mais relativo: o pesado e o leve entram em funcionamento apenas quando se produz uma situação de vórtice que pode dar origem à formação de um mundo, de modo que não têm função no movimento dos átomos absolutamente livres girando no espaço" (PARENTE, 1974, p. 15, tradução nossa). Sobre as diferenças entre as Filosofias da natureza de Epicuro e de Demócrito, o leitor pode conferir a tese de doutorado de Karl Marx (1818 - 1883), cujo título é justamente Diferença entre as filosofias da natureza em Demócrito e Epicuro (Differenz der demokritischen und epikureischen Naturphilosophie).

9 Em A Linha Reta e o Infinito da Refundação Epicureana do Atomismo (2004), de João Q. de Moraes, o leitor encontrará uma profunda e esclarecedora análise acerca dessa questão relativa movimento natural dos átomos no Epicurismo.

\begin{tabular}{|l|l|l|l|l|}
\hline Q Povista Dialectus & Ano 9 & n. 16 & Janeiro-Abril 2020 & p. $11-37$ \\
\hline
\end{tabular}


quando uma grande quantidade de átomos complementares se reúne em uma grande área do vazio (SMITH \& HAMMERSTAEDT, 2008, p. 25, tradução nossa). ${ }^{10}$

\section{V}

A vida resulta doce quando não há medo da morte. O mito do Tártaro é vão. Temos que rir da morte tal como de uma máscara que aterroriza as crianças. Ela também parece que vai morder, mas não morde (Diog. Oen. NF 130, tradução nossa).

A convergência dessa máxima com o que temos como pensamento genuíno de Epicuro pode ser constatada através das Máximas Principais, das Sentenças Vaticanas, da Carta a Meneceu e da Carta a Heródoto. A variedade de escritos a partir dos quais podemos constatar essa convergência evidencia o interesse de Epicuro no tema relativo ao medo da morte. Tal interesse se deve ao fato de ele conceber o medo da morte como uma das principais causas de perturbação da mente humana. Tanto é que o segundo aforismo do seu tetraphármakos aborda justamente esse tema: "A morte é nada para nós. Com efeito, aquilo que está decomposto é insensível e a insensibilidade é o nada para nós" (Epicur. Sent. II). ${ }^{12}$ Afirmação semelhante pode ser encontrada na seguinte passagem de sua Carta a Meneceu: “Acostuma-te à ideia de que a morte para nós não é nada, visto que todo bem e todo mal residem nas sensações, e a morte é justamente a privação das sensações" (Epicur. Ep. Men. 124).

Outro ponto a se destacar dessa máxima de Diógenes é a relação entre o tema referente ao medo da morte e a contraposição epicurea à mentalidade mítico-religiosa grega, a qual está expressa na máxima em questão sob os termos: "O mito do Tártaro é vão" (Diog. Oen. $N F$ 130, tradução nossa). Para Epicuro, há uma relação entre o medo da morte e o medo dos mitos de cunho religioso por dois motivos: (i) porque os mitos fomentam a crença de que a alma é imortal e, portanto, suscetível a castigos eternos; (ii) porque nos mitos há a ideia de que os deuses são vigilantes e vingativos. Contra a crença na imortalidade da alma, Epicuro afirma que tudo o que existe é composto por átomos, inclusive a alma (Epicur. Ep. Hdt. 63). Assim, com a morte, com a dissolução das ligações atômicas dos corpos compostos (ou seja, dos corpos dos seres humanos, dos animais e, nesse caso, também da alma), Epicuro acredita

${ }^{10}$ O leitor também poderá encontrar no Livro V do poema De Rerum Natura a argumentação epicurea relativa à 'mortalidade' do mundo. Cf. (Lucr. Fragmenta Nat. 5. vv. 65ss.).

11 O tetraphármakos epicureu consiste em uma espécie de 'remédio' composto por quatro aforismos, sendo o primeiro e o segundo voltados para a extirpação das perturbações mentais, enquanto o terceiro e o quarto aforismos são dedicados às perturbações físicas.

12 Cf.: (Epicur. Sent. Vat. II).

\begin{tabular}{|l|l|l|l|l|}
\hline Qovista Dialectus & Ano 9 & n. 16 & Janeiro - Abril 2020 & p. $11-37$ \\
\hline
\end{tabular}


desfazer a crença na vida além-túmulo e, dessa forma, nos mitos da religião grega, os quais previam para os ímpios castigos terríveis e eternos no Tártaro.

Contra os mitos referentes aos deuses vigilantes e vingativos, temos o pressuposto epicureu segundo o qual a concepção de divino alimentada pela religião não estaria em conformidade com o que de fato poderíamos (ou deveríamos) esperar de um deus. É, pois, nesse sentido que Epicuro faz a seguinte afirmação em seu tetraphármakos:

Aquele que dispõe de plenitude e de imortalidade não tem inquietações, nem preocupa os outros; por isso está isento de impulsos de cólera ou de benevolência, já que tudo isso é próprio de quem tem fraquezas (Epicur. Sent. I). ${ }^{13}$

Para Epicuro, da ideia mítico-religiosa de que os deuses seriam vigilantes em relação aos cultos prestados, e vingativos quanto à sua falta, resulta para o humano tão somente uma condição de profunda perturbação mental. Nesse sentido, Epicuro busca reformular o conceito de divino, tal como podemos observar na seguinte passagem da sua

\section{Carta a Meneceu:}

Os deuses de fato existem e é evidente o conhecimento que temos deles; já a imagem que deles faz a maioria das pessoas, essa não existe [...] Ímpio não é quem rejeita os deuses em que a maioria crê, mas sim quem atribui aos deuses os falsos juízos dessa maioria. Com efeito, os juízos do povo a respeito dos deuses não se baseiam em noções inatas [ $\left.\pi \rho{ }^{\prime} \lambda \eta \psi \imath \iota\right]$, mas em opiniões falsas. Daí a crença de que eles causam os maiores malefícios aos maus e os maiores benefícios aos bons. Irmanados pelas suas próprias virtudes, eles só aceitam a convivência com os seus semelhantes e consideram estranho tudo que seja diferente deles (Epicur. Ep. Men. 123-124).

\section{VI}

As dores mais agudas não podem persistir. Porque, ou bem ao consumir rapidamente a vida são consumidas ao mesmo tempo, ou admitem uma diminuição da sua ferocidade (Diog. Oen. 105, tradução nossa).

A máxima em questão reproduz fielmente o conteúdo do seguinte aforismo que compõe o tetraphármakos de Epicuro:

A dor contínua não dura longamente na carne. A que é extrema permanece muito pouco tempo e a que ultrapassa um pouco o prazer corporal não persiste muitos dias.

13 Cf.: (Epicur. Sent. Vat. I).

\begin{tabular}{|l|l|l|l|l|}
\hline Qovista Dialectus & Ano 9 & n. 16 & Janeiro-Abril 2020 & p. $11-37$ \\
\hline
\end{tabular}


Quanto às doenças que se prolongam, elas permitem à carne sentir mais prazer do que dor (Epicur. Sent. IV).

Sobre essa tese epicurea, cabe a seguinte observação feita por João Quartim de Moraes (2006): "Para mostrar que podemos suportar a dor, a presente máxima considera a duração da dor contínua (a passageira passa logo), relativamente a sua intensidade e a sua compatibilidade com o prazer (comentário a Epicur. Sent. IV). ${ }^{14}$ A forma como a máxima de Diógenes se apresenta não deixa claro, mas à luz do aforismo retirado do tetraphármakos, e do comentário de João Q. de Moraes, podemos facilmente identificar essa máxima como inserida na discussão epicurea relativa à possibilidade de se alcançar o prazer mesmo em períodos de dor.

O motivo pelo qual Epicuro propõe ser possível fruir o prazer mesmo diante da dor se deve à sua tese de que o fundamento da ação humana é o prazer, no sentido de que é com vistas à fruição do prazer (e afastamento da dor) que os seres humanos, por natureza, agem (Epicur. Ep. Men. 129). Nesse sentido, quando Epicuro afirma que: “A dor contínua não dura longamente na carne" (Epicur. Sent. IV), ele nos apresenta três principais razões: (i) porque dessa dor se segue a nossa morte; (ii) porque, embora contínua, não é mortal e, portanto, logo se dissipa; (iii) porque, embora advenha de uma doença que se prolonga, não acarreta na morte, permitindo, assim, à carne "sentir mais prazer do que dor" (Epicur. Sent. IV). Quer dizer, se a dor não acarreta na morte de quem a sente, então sempre haverá (do ponto de vista epicureu) a possibilidade de se fruir algum prazer em algum momento da vida.

\section{VII}

A natureza nos força a lançar gritos de dor, gemendo pelos sofrimentos. Mas é algo antinatural lamentar que não conseguimos o que gozam aqueles que desfrutam de boa saúde (Diog. Oen. 106, tradução nossa).

Os elementos contidos nessa máxima nos remetem à figura do próprio Epicuro. Ao versar sobre a vida desse filósofo, o doxógrafo grego Diógenes Laércio (III d.C.) relata

14 Embora estejamos analisando exclusivamente o comentário de João Q. de Moraes, optamos por citar como referência a obra em que esse comentário se faz presente, a saber, as Sentenças Vaticanas por ele traduzidas e comentadas. Assim, sempre que essa obra for citada deixaremos claro no texto a que precisamente nos referimos: se à própria Sentença de Epicuro (Epicur. Sent.) ou ao comentário de João Q. de Moraes acerca da Sentença em questão (comentário a Epicur. Sent.). O mesmo procedimento será aplicado nas Máximas Principais.

\begin{tabular}{|l|l|l|l|l|}
\hline Rovista Dialectus & Ano 9 & n. 16 & Janeiro-Abril 2020 & p. $11-37$ \\
\hline
\end{tabular}


que Epicuro morreu “[...] em consequência de cálculos renais, depois de passar quatorze dias enfermo [...]” (D.L. X. 15). Aliás, é também graças a Diógenes Laércio, que reproduziu em sua obra (Vidas e Doutrinas dos Filósofos Ilustres) uma carta de Epicuro endereçada a um discípulo chamado Idomeneu, que sabemos alguns detalhes sobre a condição de saúde do 'filósofo do Jardim' nos seus últimos dias. ${ }^{15}$ Eis uma passagem da carta a qual nos referimos:

Neste dia feliz, que é também o último dia de minha vida, escrevo-te esta carta. As dores contínuas resultantes da estrangúria e da disenteria são tão fortes que nada pode aumentá-las. Minha alma, entretanto, resiste a todos esses males, alegre ao relembrar os nossos colóquios passados (D.L. X. 22). ${ }^{16}$

O ponto para o qual chamamos a atenção é: mesmo sofrendo na carne as dores do cálculo renal, Epicuro não apenas "resiste", como também se "alegra" ao relembrar as conversas que teve com o seu amigo e discípulo Idomeneu. Ora, essa é a mensagem que a máxima de Diógenes busca expressar: é um equívoco reduzir a nossa existência em lamentações ocasionadas por uma má condição de saúde. Não se trata aqui, evidentemente, de um menosprezo ou insensibilidade em relação ao estado de enfermidade. Trata-se, isto sim, de uma possível resposta à questão: como ser feliz mesmo na enfermidade (ou ainda, na adversidade)? Preocupado em garantir meios possíveis para a conquista da felicidade a todos, Epicuro pressupôs o simples como o critério dessa conquista, fosse na alimentação, fosse no vestuário, na condição social e na condição física. Daí a afirmação de Tito Lucrécio Caro (97 a.C. - 54 a.C.), o poeta e epicureu romano, em sua obra De Rerum Natura: “O próprio Epicuro morreu, extinta a luz da vida, ele que superou pelo engenho a condição humana [...]” (Lucr. Fragmenta. Nat. 3. vv. 1045, grifo nosso).

\section{VIII}

Existem três classes de prazeres [...] (Diog. Oen, 107, tradução nossa).

Não há entre os textos remanescentes de Epicuro esse tipo de divisão dos prazeres. O que temos é a diferenciação acerca dos prazeres somáticos e do prazer advindo do

15 Epicuro é comumente referenciado na História da Filosofia como o 'filósofo do Jardim' pelo fato de a sua escola ter sido edificada em uma casa circundada por um grande jardim - local onde Epicuro se reunia com os seus discípulos. Cf.: (SPINELLI, 2009, p. 30).

16 A estrangúria é um dos sintomas do cálculo renal. Tal sintoma consiste na eliminação lenta e dolorosa da urina.

\begin{tabular}{|l|l|l|l|l|}
\hline Q Povista Dialectus & Ano 9 & n. 16 & Janeiro - Abril 2020 & p. $11-37$ \\
\hline
\end{tabular}


estado de ataraxia - portanto, 'duas classes de prazeres'. Epicuro nos apresenta essa diferenciação em sua Carta a Meneceu ao fazer a seguinte afirmação:

\begin{abstract}
Quando então dizemos que o fim último é o prazer, não nos referimos aos prazeres dos intemperantes ou aos que consistem no gozo dos sentidos, como acreditam certas pessoas que ignoram o nosso pensamento, ou não concordam com ele, ou o interpretam erroneamente, mas ao prazer que é ausência de sofrimentos físicos e de perturbações da alma (Epicur. Ep. Men. 131).
\end{abstract}

Mesmo quando consideramos a genuína tese epicurea segundo a qual os prazeres diferem entre si (Epicur. Sent. IX), não constatamos a pretendida divisão dos prazeres em três classes, como afirma Diógenes. Isso porque, para Epicuro, a diferença entre os prazeres se resume apenas em duas: ou determinada sensação prazerosa constitui-se em um benefício para a conquista/manutenção de uma vida feliz, ou essa determinada sensação prazerosa é maléfica para tal propósito. Daí a máxima epicurea segundo a qual: "Nenhum prazer é em si mesmo um mal, mas aquilo que produz certos prazeres acarreta sofrimentos bem maiores do que os prazeres" (Epicur. Sent. VIII, grifo nosso), sendo, portanto, necessário uma espécie de 'cálculo prudencial' relativo à viabilidade da fruição desse prazer. Sobre o conteúdo específico dessa máxima de Epicuro, cabe o esclarecedor comentário feito por João Q. de Moraes em sua tradução:

Consideremos dois exemplos demasiado frequentes, o alcoolismo e as drogas. Os prazeres proporcionados pelo vinho, pela coca ou pelo ópio não são maus em si mesmos. Ao contrário: não há quem negue que o vinho faz bem (os cristãos dele fizeram o veículo em que se materializa o sangue de Deus feito homem). Quanto à coca, desde o fundo dos tempos, os primitivos habitantes do Altiplano e da Cordilheira dos Andes mascavam-na para suportar o oxigênio rarefeito das alturas em que viviam e também como anestésico para a fome a que constantemente estavam submetidos. A moderna medicina utiliza seu mais moderno derivado, a cocaína, como um anestésico, que como o ópio, serve para aplacar dores físicas atrozes. Entretanto, usados sem critério médico e sobretudo, manipulados por criminosos, cocaína e ópio transformam os viciados em farrapos humanos (comentário a Epicur. Sent. VIII).

IX

Os desejos vãos, como os da glória e similares, não são apenas vãos, mas também são difíceis de se conseguir. Não difere muito do de beber muito e seguir constantemente tendo sede. Ter conquistado, mas com pesar, [é vantagem vã] (Diog. Oen. 109, tradução nossa). 
A máxima em questão faz referência à classificação dos desejos (epithymíai) apresentada por Epicuro, tanto em sua Carta a Meneceu (Epicur. Ep. Men. 127), quanto em suas Máximas Principais (Epicur. Sent. XXIX) e Sentenças Vaticanas (Epicur. Sent Vat. 20). Fundamentalmente, tal classificação consiste na evidenciação de que existem desejos naturais (physikós) e desejos vãos (kenós: frívolos ou vazios). Os desejos naturais dividem-se em duas classes: (i) os necessários, em cuja categoria encontram-se também os desejos fundamentais para a felicidade, o bem-estar corporal e a própria vida; (ii) os desejos apenas naturais (Epicur. Ep. Men. 127). Sobre essa divisão dos desejos, Diógenes Laércio faz o seguinte (e essencial) esclarecimento:

\footnotetext{
Epicuro considera naturais e necessários os desejos que nos livram do sofrimento, como beber quando temos sede; naturais e não-necessários são os desejos que simplesmente fazem variar o prazer, sem remover o sofrimento, como os alimentos suntuosamente preparados; nem naturais nem necessários são os desejos por coroas e ereção de estátuas em honra da própria pessoa (D.L. X. 149, grifo nosso).
}

Os desejos "nem naturais nem necessários" mencionados por Diógenes Laércio são justamente os desejos vãos aos quais Diógenes (de Enoanda) se refere em sua máxima. Tratam-se de desejos forjados pela mente humana e, por vezes, confundidos como desejos naturais e necessários. No entanto, atenta Epicuro, tais desejos são facilmente controlados quando temos clareza acerca da sua 'natureza', qual seja, não ser necessário:

Dentre os desejos, aqueles que não provocam padecimento quando permanecem insatisfeitos não são necessários, podendo suas pulsões ser facilmente controladas se eles nos parecem difíceis de atingir ou suscetíveis de nos causar danos (Epicur. Sent. XXVI).

\section{$\mathbf{X}$}

Em poucas ocasiões o acaso, que chamamos de fortuna ou de azar, decide o curso da vida; na grande maioria nós é que dominamos (Diog. Oen. 111, tradução nossa).

A máxima em questão está de acordo com o que Epicuro afirma tanto em suas Máximas Principais (Epicur. Sent. XVI) quanto em sua Carta a Meneceu (Epicur. Ep. Men. 133-134), pois, de fato, ele admitia não só o acaso (týche ), mas também uma autonomia (autárkeia) da ação humana. Fundamentalmente, essa postura de Epicuro relativa ao acaso e à autonomia da ação nasce da sua contraposição teórica ao determinismo defendido por

\begin{tabular}{|l|l|l|l|l|}
\hline Q Povista Dialectus & Ano 9 & n. 16 & Janeiro - Abril 2020 & p. $11-37$ \\
\hline
\end{tabular}


Demócrito. Para o filósofo de Abdera: “Tudo acontece por força da necessidade [ảvó $\gamma \kappa \eta]$ [...]” (D.L. IX. 45), ao passo que, para Epicuro: “[...] as coisas acontecem ou por necessidade

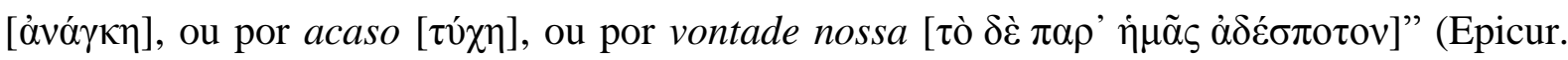
Ep. Men. 133, grifo nosso). Quer dizer: Epicuro não nega que certas coisas acontecem por necessidade (a morte é um bom exemplo disso). O que ele nega é a tese de que que absolutamente 'tudo' acontece por força da necessidade. Daí a sua afirmação segundo a qual:

Mais vale aceitar o mito dos deuses, do que ser escravo do destino dos naturalistas: o mito pelo menos nos oferece a esperança do perdão dos deuses através das homenagens que lhes prestamos, ao passo que o destino é uma necessidade inexorável (Epicur. Ep. Men. 134).

No que diz respeito especificamente ao acaso, a postura de Epicuro é a de quem reconhece a sua existência - ao contrário de Demócrito. Entretanto, seus ensinamentos são sempre no sentido de fazer com que os seus discípulos não esperem que a felicidade seja alcançada pelo acaso. Um bom exemplo disso está contido na seguinte Sentença Vaticana:

Antecipei-me a ti, Fortuna, e bloqueei todas as brechas por onde poderias passar. E não vamos nos entregar como cativos teus ou de outrem em nenhuma circunstância; mas, quando for tempo de irmos, cuspiremos com desdém na vida e naqueles inutilmente apegados a ela. Deixaremos a vida com uma canção de triunfo por termos vivido bem (Epicur. Sent. Vat. 47).

Ou ainda, na seguinte passagem da Carta a Meneceu:

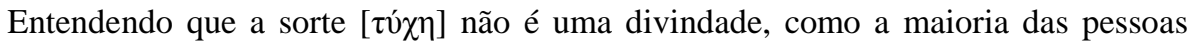
acredita (pois um deus não faz nada ao acaso), nem algo incerto, o sábio não crê que ela proporcione aos homens nenhum bem ou nenhum mal que sejam fundamentais para uma vida feliz, mas, sim, que dela pode surgir o início de grandes bens e de grandes males (Epicur. Ep. Men. 134.).

Tal como afirmamos na análise referente à máxima $\mathbf{I}$, para Epicuro, a conquista da felicidade é de inteira responsabilidade daquele que a deseja, e não do acaso, ou ainda, dos familiares, dos amigos ou dos deuses. Isso também não significa, vale esclarecer, que Epicuro pressupôs o isolamento da família, dos amigos e dos deuses como a condição sine qua non para a conquista de uma vida feliz. O projeto filosófico de Epicuro visava a conquista do viver

\begin{tabular}{|l|l|l|l|l|}
\hline Q Rovista Dialectus & Ano 9 & n. 16 & Janeiro-Abril 2020 & p. $11-37$ \\
\hline
\end{tabular}


bem e feliz, quer consigo mesmo, quer na relação com os demais. ${ }^{17}$ Acontece que, para Epicuro, a responsabilidade pela conquista da vida feliz não pode ser imputada aos outros, como se os amigos, cônjuges, etc., tivessem a obrigação de nos 'fazer felizes'.

\section{XI}

É uma desgraça que aqueles que adoecem da paixão erótica ignorem que o prazer supremo chega pela contemplação, independente do contato sexual; e que o prazer sexual em si é o mesmo, seja com uma pessoa bonita ou uma feia (Diog. Oen. $N F$ 157, tradução nossa).

A presente máxima é interessante devido ela suscitar a seguinte questão: para os epicureus, os prazeres diferem ou não diferem? ${ }^{18}$ Quando consideramos a primeira parte da máxima, que afirma ser “[...] uma desgraça que aqueles que adoecem da paixão erótica ignorem que o prazer supremo chega pela contemplação, independente do contato sexual [...]", temos um claro esforço no sentido de evidenciar a diferença entre o prazer fruído da "paixão erótica" e o "prazer supremo" conquistado pela "contemplação". Tal esforço nasce como reação aos constantes ataques à doutrina feitos pelos adversários de Epicuro. Conforme relata Diógenes Laércio, os maiores detratores da Filosofia epicurea foram os estoicos, pois eles não só afirmavam que Epicuro fazia passar por sua a doutrina hedonista de Aristipo de Cirene (435 a.C. - 356 a.C.), como também que Epicuro teria prostituído um de seus irmãos e que convivia com uma cortesã (etaíra) (D.L. X. 4). Os adversários do Epicurismo trabalharam em prol da construção de um Epicurismo caricato, sobretudo no que dizia respeito à fruição dos prazeres. Daí a intenção de Diógenes em evidenciar a diferença entre o prazer proveniente da "paixão erótica" e o "prazer supremo que chega pela contemplação" ou ainda, a diferença entre ele (um epicureu) e os que "adoecem".

Quanto à segunda parte da máxima, de acordo com a qual “[...] o prazer sexual em si é o mesmo, seja com uma pessoa bonita ou uma feia”, ele nos remete imediatamente à seguinte Máxima Principal:

17 Sobre a importância que Epicuro deu para a amizade, conferir: (Epicur. Sent. XXVII); (Epicur. Sent. Vat. 66. 78); (D.L. X. 118. 120).

18 Na verdade, para além dessa questão que aqui enunciamos, a máxima 157 de Diógenes também suscitou outras questões entre os especialistas Hammerstaedt e Smith. Foi Pamela Gordon (2016) quem observou essa divergência em sua Resenha da obra The Epicurean Inscription of Diogenes of Oinoanda: Ten Years of New Discoveries and Research (2014), a qual pode ser acessada em: http://bmcr.brynmawr.edu/2016/201607-38.html.

\begin{tabular}{|l|l|l|l|l|}
\hline Q Povista Dialectus & Ano 9 & n. 16 & Janeiro - Abril 2020 & p. $11-37$ \\
\hline
\end{tabular}


Se todo prazer pudesse ter se acumulado, não só persistindo no tempo, mas também percorrendo a inteira composição de nosso corpo, ou pelo menos as principais partes de nossa natureza, então os prazeres não difeririam entre si (Epicur. Sent. IX).

Ao comentar essa Máxima de Epicuro, João Q. de Moraes aponta para o fato de que o seu argumento "[...] parte de uma condição irreal, introduzida pela conjunção غ̇ı ou por

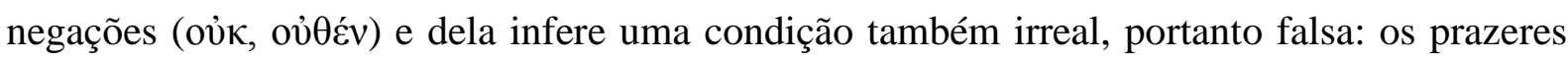
não diferem" (comentário a Epicur. Sent. IX). De fato, tal como já observamos na análise da máxima VIII, para Epicuro, há diferença entre os prazeres, visto que: (i) ou o prazer é somático (consiste apenas no gozo dos sentidos); (ii) ou é o prazer da ataraxia, que dizer, advém da ausência de perturbações físicas e mentais (Epicur. Ep. Men. 131). Nesse sentido, considerando a máxima de Diógenes como um todo, afirmamos que ela não pretende sustentar que os prazeres não diferem. O que Diógenes deseja esclarecer é que, relativo especificamente ao gozo dos prazeres somáticos (nesse caso, os prazeres sexuais), não há qualquer diferença entre eles. Curiosamente, vale mencionar, esse pressuposto defendido por Epicuro o coloca em posição diametralmente contrária à posição de Aristipo, para quem: “Um prazer não difere de outro prazer, nem um prazer é mais agradável que outro [...]” (D.L. II. 87).

\section{XII}

Temos que pensar que a riqueza que excede a medida natural não é mais útil que a água que transborda de um cântaro e que se tem que derramar fora. Podemos contemplar as riquezas dos outros sem inveja e até mesmo desfrutar delas de modo mais sereno, já que estamos livres de nos preocuparmos com elas (Diog. Oen. 108, tradução nossa).

Essa máxima nos apresenta à discussão epicurea relativa ao conceito de riqueza ( $\pi \lambda$ oṽ $\left.\varsigma_{\zeta}\right)$. Sobre essa discussão, as considerações feitas por João Q. de Moraes na sua tradução das Sentenças Vaticanas são imprescindíveis. Tais considerações são feitas à luz da seguinte Sentença epicurea: “A pobreza medida pela finalidade da natureza é uma grande riqueza; a riqueza, se não limitada, é uma grande pobreza" (Epicur. Sent. Vat. 25). ${ }^{19}$ Acerca dessa Sentença, João Q. de Moraes afirma:

A reflexão sobre o conceito de riqueza $(\pi \lambda$ oṽ $\tau$ $\varsigma$ ) nos parece notável porque põe em evidência seu caráter relativo, sem cair no relativismo dos sofistas.

19 Nesse mesmo sentido, temos também a seguinte Sentença: “A riqueza da natureza é fácil de adquirir; a que corresponde às vãs opiniões estende-se ao infinito e é difícil de obter" (Epicur. Sent. Vat. 8).

\begin{tabular}{|l|c|c|c|c|}
\hline Q Povista Dialectus & Ano 9 & n. 16 & Janeiro - Abril 2020 & p. $11-37$ \\
\hline
\end{tabular}


No sentido vulgar do termo, pobre é quem possui poucos bens, ricos é quem possui muitos. Segundo a natureza, entretanto, riqueza é tudo que satisfaz às carências vitais dos humanos (comentário a Epicur. Sent. Vat. 25).

Quando Diógenes se refere à "riqueza que excede a medida natural" o que está em questão é justamente essa relação conflituosa (evidenciada por João Q. de Moraes) entre o ser rico, enquanto 'possuidor de bens', e o ser rico no sentido de 'dispor de tudo o que o ser humano carece por natureza'. Contudo, Diógenes não quer com isso defender a ideia de que aos 'financeiramente ricos' é vetada a possibilidade de se conquistar a felicidade aos moldes da Filosofia epicurea. Tanto é verdade que, logo na sequência, Diógenes afirma: "Podemos contemplar as riquezas dos outros sem inveja e até mesmo desfrutar delas [...]", evidenciando, dessa forma, que o problema epicureu não é com o 'ser financeiramente rico', mas sim, com o modo como o humano se comporta frente a esse tipo de riqueza.

Quando analisamos os textos remanescentes de Epicuro, constatamos que não há neles uma defesa pela pobreza: como se a felicidade só fosse alcançada apenas pela miséria. Daí a afirmação de João Q. de Moraes:

Não se trata, porém, de sustentar o culto à pobreza vulgarizado pelas éticas de índole ascética, cristã ou simplesmente conformista, que contrapõem o rico infeliz no meio de sua opulência ao pobre feliz na penúria. Despojar-se dos próprios bens ou simplesmente dispor de poucos bens, isto é, ser pobre no sentido vulgar, não torna ninguém feliz (comentário a Epicur. Sent. Vat. 25).

É a forma (ou a disposição) como nos portamos perante a penúria (ou a riqueza) que irá determinar se nós seremos ou não felizes. ${ }^{20}$ É, pois, nesse sentido que Epicuro fez as seguintes afirmações em sua Carta a Meneceu:

\begin{abstract}
Consideramos ainda a autossuficiência um grande bem; não que devamos nos satisfazer com pouco, mas para nos contentarmos com esse pouco caso não tenhamos o muito, honestamente convencidos de que desfrutam melhor a abundância os que menos dependem dela [...] Habituar-se às coisas simples, a um modo de vida não luxuoso, portanto, não só é conveniente para a saúde, como ainda proporciona ao homem os meios para enfrentar corajosamente as adversidades da vida [...] (Epicur. Ep. Men. 130-131).
\end{abstract}

Nesse sentido, só nos resta concluir que a máxima de Diógenes em questão está de fato em conformidade com a Filosofia de Epicuro.

20 Tema da máxima 112 (XV), a qual analisaremos adiante.

\begin{tabular}{|l|c|c|c|c|}
\hline Qevista Dialectus & Ano 9 & n. 16 & Janeiro-Abril 2020 & p. $11-37$ \\
\hline
\end{tabular}




\section{XIII}

Comidas muito requintadas e bebidas... de modo algum produzem segurança e um hábito confortável ao corpo (Diog. Oen. 109, tradução nossa).

Estreitamente relacionada com o que foi exposto acima (Diog. Oen. 108), a máxima em questão expressa o pressuposto genuinamente epicureu segundo o qual a conquista de uma vida feliz (makários zenn) não carece de comidas e bebidas requintadas. Para Epicuro, no que diz respeito à conquista de uma vida feliz, pouco importa o requinte da comida e da bebida, porque não é disso que a natureza humana carece, seja para levar uma existência saudável (e, portanto, sem as dores das doenças e, consequentemente, sem perturbações físicas; em ataraxia), seja para simplesmente sobreviver. É por esse motivo que Epicuro afirma em sua Carta a Meneceu que:

Os alimentos mais simples proporcionam o mesmo prazer que as iguarias mais requintadas, desde que se remova a dor provocada pela falta: pão e água produzem o prazer mais profundo quando ingeridos por quem deles necessita (Epicur. Ep. Men. 130-131).

Do ponto de vista epicureu, a natureza humana carece é da remoção das dores psíquicas provocadas pela ausência das comidas e bebidas requintadas. Tal remoção só se dá mediante uma análise dos desejos humanos, os quais Epicuro classifica como naturais (physikós) e vãos (kenós: frívolos; inúteis; vazios). Dado que esse é o tema da máxima de Diógenes que se segue, vamos a ela.

\section{XIV}

[...] Diga-nos, dos desejos, quais são naturais e quais são vãos.

Não é a natureza, que é única para todos, que distingue o nobre e o ignóbil, mas as ações e as disposições de ânimo (Diog. Oen. 111, tradução nossa).

Em sua Carta a Meneceu, Epicuro nos apresenta a sua classificação dos desejos da seguinte forma:

\begin{tabular}{|c|c|c|c|c|}
\hline Qovista Dialectus & Ano 9 & n. 16 & Janeiro - Abril 2020 & p. $11-37$ \\
\hline
\end{tabular}


dentre os necessários, há alguns que são fundamentais para a felicidade, outros, para o bem-estar corporal, outros, ainda, para a própria vida (Epicur. Ep. Men. 127).

Já nos referimos a essa classificação dos desejos ao analisarmos a máxima $\mathbf{I X ,}$ inclusive reproduzindo as explicações de Diógenes Laércio acerca dessa classificação. Nesse sentido, o que cabe evidenciar aqui é que: é em razão dessa classificação dos desejos proposta pelo próprio Epicuro que Diógenes afirma não ser a natureza, “[...] que é única para todos, que distingue o nobre e o ignóbil, mas as ações e as disposições de ânimo" (Diog. Oen. 111, tradução nossa). Isso porque, tal como expusemos na análise das máximas XIII e XIV, o problema não está no requinte dos alimentos em si, mas no modo como nos dispomos em relação a eles. Em momento algum Epicuro afirma que devemos nos abster dos alimentos requintados. O que ele prescreve é que devemos 'remover a dor psíquica provocada pela sua falta', pois, do contrário, passamos a atribuir ao requinte desses alimentos (ao desejo vão por eles) a condição sine qua non para a conquista da felicidade.

\section{XV}

O fundamental na felicidade é a nossa disposição de ânimo, da qual somos donos (Diog. Oen. 112, tradução nossa).

Nessa máxima, constatamos um reforço da tese genuinamente epicurea segundo a qual a conquista da felicidade depende exclusivamente de uma disposição de ânimo (diáthesis tes psyches) particular. É possível enxergar nas condições político-sociais da Grécia do tempo de Epicuro os motivos pelos quais esse filósofo elaborou tal pressuposto. Com a perda da autonomia política da Grécia para a Macedônia no século IV a.C., e com o seu enfraquecimento no âmbito do comércio - sobretudo do ateniense, visto Alexandria ter se tornado o novo centro comercial -, a dificuldade dos mais pobres para sobreviver aumenta cada vez mais e o terreno se torna fértil para o surgimento de um modo de viver e de pensar nos moldes da Filosofia epicurea:

Quando o ideal cívico criado pela cidade-Estado se desmoronou, os habitantes mais ponderados dos Estados helenísticos procuraram febrilmente um significado da vida, um ideal e regras de conduta. Poucos podiam encontrar consolo na religião; mas a educação puramente racionalista dada pela filosofia no passado produzira seus efeitos e a maioria procurou uma resposta às suas dúvidas não em Deus, mas na razão. E as respostas vieram dos cínicos, estoicos e epicuristas (ROSTOVTZEFF, 1983, p. 301).

\begin{tabular}{|l|l|l|l|l|}
\hline Q Revista Dialectus & Ano 9 & n. 16 & Janeiro-Abril 2020 & p. $11-37$ \\
\hline
\end{tabular}


A resposta de Epicuro foi justamente fazer com que a felicidade repousasse não no possuir bens, mas em uma disposição de ânimo específica (a ataraxia) relativa às condições econômicas, políticas, psíquicas, etc., de cada um. Foi, pois, nesse sentido que Epicuro recomendou: (i) ao rico, que vivesse de maneira comedida; (ii) ao pobre, que não restringisse a sua felicidade à capacidade de acumular riquezas. Isso justamente porque, do ponto de vista epicureu, a conquista da felicidade não se dá através da quantidade de bens que somos capazes de acumular, mas tão somente na forma como nos dispomos em relação à nossa condição econômica, política ou religiosa. Daí o seu esforço em evidenciar que, por natureza, os seres humanos carecem de muito pouco para satisfazerem as suas necessidades e, dessa forma, extirparem as suas perturbações físicas e psíquicas. Pressupondo o pouco e o simples como o necessário para se alcançar uma vida feliz, Epicuro procurou dar uma resposta filosófica aos problemas sociais da sua época; resposta essa que colocava exclusivamente no humano particularmente considerado a responsabilidade por sua felicidade.

\section{XVI}

Nada há que produza tanta felicidade de ânimo como o não se ocupar de muitos assuntos, nem empreender tarefas de difícil solução, nem se empenhar em algo que está para além dos nossos próprios recursos. Porque tudo isso causa perturbações à nossa natureza (Diog. Oen. 113, tradução nossa).

Relativo ao tema dessa máxima de Diógenes, temos entre as Sentenças Vaticanas o seguinte ensinamento de Epicuro: "Liberemos a nós mesmos da prisão dos assuntos cotidianos e públicos" (Epicur. Sent. Vat. 58). Aliado a esse ensinamento, temos ainda um testemunho de Diógenes Laércio segundo o qual, em uma obra intitulada Dos Modos de Viver, Epicuro teria afirmado que o sábio não “[...] participará da vida pública” (D.L. X. 119). Tal como “[...] o não se ocupar de muitos assuntos, nem empreender tarefas de difícil solução, nem se empenhar em algo que está para além dos nossos próprios recursos" enunciado por Diógenes, o distanciamento da vida pública aconselhado por Epicuro também se justifica em razão do risco de se prejudicar o almejado estado de imperturbabilidade (a ataraxia). Essa postura de Epicuro em relação à política (e, por extensão, aos pontos

\begin{tabular}{|l|l|l|l|l|}
\hline Q Povista Dialectus & Ano 9 & n. 16 & Janeiro-Abril 2020 & p. $11-37$ \\
\hline
\end{tabular}


apresentados por Diógenes) se deve à sua máxima láthe biôsas: viva escondido. Sobre o sentido dessa máxima, as seguintes considerações de Spinelli são essenciais:

\begin{abstract}
É fato que Epicuro propunha um distanciamento da vida política, no entanto sua máxima, a láthe biôsas, viva escondido ou oculte a tua vida, não expressa rigorosamente mera fuga do cotidiano ou da vida pública, e sim um apelo à interioridade. No que dizia respeito aos afazeres públicos, a láthe biôsas comportava um sentido de não engajamento, e Epicuro tinha uma boa razão para isso: porque naquela ocasião (numa época de dominação externa em que tudo era controlado pelo poder central da Macedônia) um engajamento em sentido próprio se impunha, primeiro, por escolha preestabelecida por vontade deliberada do poder do império; segundo, porque, naquele momento e naquelas condições, engajar-se significava o mesmo que abrir mão da própria autonomia (autárkeia) e, portanto, subjugar até o que de mais nobre restava: a própria interioridade (SPINELLI, 2009, p. 157-158).
\end{abstract}

Uma última observação a ser feita sobre esse distanciamento da vida pública como condição para se alcançar a vida feliz epicurea é o fato de ela consistir em um ponto de divergência com os estoicos. Ao contrário dos epicureus, os estoicos (lato sensu) não 'enxergavam' na participação (ocupação) de cargos públicos qualquer empecilho para a conquista da vida feliz. Isso pode ser constatado na seguinte passagem da obra Vidas e

\title{
Doutrinas dos Filósofos Ilustres:
}

No primeiro livro de sua obra Dos Modos de Vida, Crisipo [um dos mais proeminentes discípulos de Zenão] sustenta que o sábio participará da vida política, se nada o impedir, pois assim ele conterá a deficiência e propagará a excelência (D.L. VII. 121).

Se, por um lado, temos Epicuro e os epicureus se ausentando dos assuntos públicos, por outro, temos Zenão (340 a.C. - 264 a.C.) e os estoicos que, não apenas incentivavam a participação em tais assuntos, como também eram próximos das figuras políticas de seu tempo - ou seja, o mesmo tempo de Epicuro, o tempo de dominação da Macedônia sobre a Grécia. Um bom exemplo nesse sentido é o próprio Zenão, dada a sua proximidade com o rei macedônio Antígono Gônatas II (319 a.C. - 239 a.C.), o descendente de Antígono Monoftalmo (382 a.C. - 301 a.C.), um dos generais de Alexandre, o Grande (336 a.C. - 323 a.C.). Da relação entre Zenão e o rei macedônio, Diógenes Laércio nos oferece os seguintes testemunhos:

\begin{tabular}{|l|l|l|l|l|}
\hline Q Rovista Dialectus & Ano 9 & n. 16 & Janeiro-Abril 2020 & p. $11-37$ \\
\hline
\end{tabular}


Antígonos Gonatas também o distinguiu [ou seja, Zenão], e todas as vezes que vinha a Atenas ia ouvir suas lições, além de convidá-lo frequentemente a ir à sua corte. Zenão recusou os convites, porém mandou Persaios, um de seus amigos - filho de Demétrios, natural de Cítion, que estava no apogeu na $130^{\text {a }}$ Olímpiada -, quando Zenão já era velho (D.L. VII. 6). ${ }^{21}$

\title{
XVII
}

Para você e para aqueles que virão depois de você... com a ânsia de te convencer... é típico do esforço acompanhado de simpatia... e de uma contínua prática da virtude. Bem, aí está o meio para a salvação. Caso você ainda não tenha chegado à consciência dessas coisas, deixamos todas essas linhas gravadas em pedra (Diog. Oen. 116, tradução nossa).

Por se tratar de uma máxima fragmentada, optamos por comentar apenas a sua segunda parte, qual seja: "Bem, aí está o meio para a salvação. Caso você ainda não tenha chegado à consciência dessas coisas, deixamos todas essas linhas gravadas em pedra". Nessa segunda parte constatamos o aspecto filantrópico do projeto de Diógenes: gravar em pedra os ensinamentos de Epicuro no intuito de 'salvar' (ou 'auxiliar' - epikoureîn) aqueles que se dispusessem a aprendê-los. Em sua obra El sabio camino hacia la felicidad: Diógenes de Enoanda y el gran mural epicúreo, Gual dedica um total de 15 páginas ao tema da filantropia epicurea expressa no muro de Diógenes. ${ }^{22}$ Dessas páginas, citamos aqui as seguintes afirmações de Gual que consideramos fundamentais no que diz respeito à filantropia de Diógenes:

\begin{abstract}
A filantropia se apresenta nesta época [na de Diógenes] como uma qualidade própria da civilização grega, como uma característica e uma virtude do helenismo, e com esses tons se transmite até o final do paganismo em pleno século IV [...] Em sua concepção de filantropia, Diógenes de Enoanda retoma, de forma singular, a concepção helenística desse amor ao gênero humano, sem distinção de raças ou nações [...] Em sua mensagem universal, este velho epicureu de Enoanda se apresenta como um generoso benfeitor que oferece, desde a sua satisfeita velhice em dysmaîs tou bíou -, o testemunho de sua experiência bem-aventurada àquele que, com bom juízo, quiser aproveitá-la para conquistar a felicidade terrena. Essa ideia foi a característica mais original da sua vida. Foi o amor ao próximo, essa filantropia, que justificou esse notório gasto da sua fortuna (GUAL, 2016, p. 121122, tradução nossa).
\end{abstract}

21 Na sequência (D.L. VII. 7. 9) o leitor interessado poderá encontrar a reprodução de cartas trocadas entre Antígono e Zenão. Diógenes Laércio reproduz tais cartas a partir de uma obra de Apolônio de Tiro sobre Zenão.

22 Nos referimos ao capítulo intitulado Filantropía epicúrea. La inscripción de Diógenes de Enoanda y su afán benéfico (GUAL, 2016, p. 109-123).

\begin{tabular}{|l|l|l|l|c|}
\hline Revista Dialectus & Ano 9 & n. 16 & Janeiro - Abril 2020 & p. $11-37$ \\
\hline
\end{tabular}


Do que foi citado, vale explicar a afirmação de que a ideia de construir o muro com os ensinamentos de Epicuro "[...] foi a característica mais original [...]" da vida de Diógenes. Gual afirma isso pelo seguinte motivo: ao contrário dos discípulos de Zenão de Cítio, os discípulos de Epicuro, em geral, não colocavam em 'crise' os fundamentos da doutrina. $^{23}$ Todo o esforço era empregado apenas no sentido de compreendê-la e transmiti-la. Um bom exemplo nesse sentido (para além de Diógenes de Enoanda) é o próprio poema de Lucrécio (De Rerum Natura): não há ali qualquer tentativa de 'inovar' a doutrina epicurea, mas tão somente transmiti-la e esclarecê-la, de modo a não deixá-la 'morrer', dados os sucessivos ataques feitos à ela pelos adversários do Epicurismo.

\section{XVIII}

Assim como não é possível morrer duas vezes, viver duas vezes também não o é. Temos que ter ânimo ao morrer, pois não nos vemos privados apenas dos bens, mas também dos males. Vá com coragem! (Adeus.) (Diog. Oen. NF 209, tradução nossa).

Embora seja possível estabelecer uma relação de convergência entre essa última máxima de Diógenes e os pressupostos genuínos de Epicuro, é interessante observar que Diógenes muda um pouco a direção da discussão na qual esse pressuposto está inserido entre as Sentenças de Epicuro. Afirmamos isso, pois, nas Sentenças Vaticanas podemos ler o seguinte ensinamento:

Nascemos só uma vez, não é possível nascer duas vezes, teremos de não ser por toda a eternidade. Tu, porém, que não és de amanhã, postergas tua alegria; mas a vida se desperdiça com a demora e cada um de nós morre envolvido em seus afazeres (Epicur. Sent. Vat. 14).

Na mesma linha de raciocínio, encontramos ainda as Sentenças 17, 19, 30, $31^{24} \mathrm{e}$ $60 .^{25} \mathrm{O}$ foco de Epicuro nas Sentenças mencionadas está voltado para a evidenciação não apenas da brevidade da vida, mas também (e em especial) da ideia de que as pessoas postergam a própria felicidade em nome do cumprimento de certos afazeres que, por vezes,

23 Sobre a postura dos estoicos relativa aos ensinamentos de Zenão, conferir: SEDLEY, D. A Escola, de Zenão a Ário Dídimo. In: INWOOD, B. (Org.). Os Estoicos. Trad. Raul Fiker. São Paulo: Odysseus, 2006.

24 Estobeu atribuiu essa Sentença a Metrodoro, o "ilustre" discípulo de Epicuro (D.L. X. 22. 23). Cf.: (comentário a Epicuro. Sent. Vat. 31).

25 Como bem observa João Q. de Moraes em sua tradução das Sentenças Vaticanas. Cf.: (comentário a Epicur. Sent. Vat. 14).

\begin{tabular}{|l|l|l|l|l|}
\hline Qovista Dialectus & Ano 9 & n. 16 & Janeiro-Abril 2020 & p. $11-37$ \\
\hline
\end{tabular}


promovem até mesmo o distanciamento de uma condição de vida feliz. Nesse sentido, se, por um lado, Epicuro discute a questão relativa à brevidade da vida a partir de pressupostos que enaltecem o 'saber envelhecer', por outro, temos Diógenes abordando a mesma questão, porém, a partir da ideia de que, dada a brevidade da vida, devemos 'saber morrer'.

O ‘saber morrer’ de Diógenes, cabe esclarecer, não está em contradição com o que afirmou Epicuro em sua Carta a Meneceu. Nos referimos à seguinte passagem dessa Carta:

Quem aconselha o jovem a viver bem e o velho a morrer bem não passa de um tolo, não só pelo que a vida tem de agradável para ambos, mas também porque se deve ter exatamente o mesmo cuidado em honestamente viver e em honestamente morrer (Epicur. Ep. Men. 126).

Em conformidade com os pressupostos de Epicuro, o 'saber morrer' (ou o 'ter ânimo para a morte') de Diógenes se dá tão somente no sentido de um necessário reconhecimento dos limites da natureza humana e, consequentemente, na fruição de uma vida feliz. Sobre esse ponto da doutrina epicurea, é esclarecedora as considerações de Spinelli em sua obra Caminhos de Epicuro. Afirma Spinelli:

\footnotetext{
Pelo que está dito [refere-se à passagem 126 da Carta a Meneceu], a questão imposta (e fazendo aqui uso de uma metáfora) não é que a morte para Epicuro seja um ato derradeiro, como se fosse a última pancada do relógio: a morte, ao contrário, é um movimento (de vida) que se realiza a exemplo do desenrolar da corda que ao relógio foi dada. Daí a insensatez de achar que o jovem deve ser incentivado a viver bem e o velho a morrer bem. Ora, viver bem e morrer bem coincidem, de tal modo que quem bem não vive morrer jamais saberá. Daí, por fim, que a filosofia de Epicuro não é uma preparação para bem morrer, embora o seja, e sim a proposição de um exercício constante para o bem viver [...] (SPINELLI, 2009, p. 231-232).
}

Na medida em que a máxima de Diógenes chama a atenção para a ideia de que não há nada de terrível em morrer, podemos afirmar que entre ela e a Filosofia de Epicuro não existem divergências. Tal como a Carta a Meneceu de Epicuro, a tônica da máxima de Diógenes está no 'saber viver', ainda que tal ensinamento esteja construído a partir da ideia de se aceitar a morte.

\section{Referências}

CÍCERO. Do Sumo bem e do Sumo Mal. Trad. Carlos Ancêde Nougué. São Paulo: Martins Fontes, 2005.

\begin{tabular}{|l|l|l|l|l|}
\hline Q Povista Dialectus & Ano 9 & n. 16 & Janeiro-Abril 2020 & p. $11-37$ \\
\hline
\end{tabular}


. De Finibus Bonorum et Malorum. Translation by Harris Rackham, M.A. London: William Heinemann, 1914 (https://archive.org).

DIÓGENES LAÉRCIO. Vidas e Doutrinas dos Filósofos Ilustres. Trad. Mário da Gama Kury. Brasília: Editora Universidade de Brasília, 2008.

EPICURO. Lettres et Maximes. Texte Étable et Traduit avec une Introduction et des Notes par Marcel Conche. Paris: Presses Universitaires de France, 1987.

Unesp, 2002.

Carta a Meneceu. Trad. Álvaro Lorencini e Enzo Dell Carratore. São Paulo:

Máximas Principais. Introdução, tradução e notas de João Quartim de Moraes. Campinas (SP): IFCH/UNICAMP, 2006 (Coleção Clássicos da Filosofia: Cadernos de Tradução, $\mathrm{n}^{\mathbf{0}}$ 13).

Sentenças Vaticanas. Texto, tradução e comentários de João Quartim de Moraes. São Paulo: Loyola, 2014 (Coleção Clássicos da Filosofia).

GUAL, C. G. El Sábio Camino Hacia La Felicidad. Diógenes de Enoanda Y El Gran Mural Epicúreo. Barcelona: Editorial Planeta, S.A., 2016.

GOODMAN, L. E. \& AIKIN, S. What did Epicurus Learn from Plato? In: Philosophy 92

(3), 421-447. Disponível em: https://doi.org/10.1017/S0031819117000110

HAMMERSTAEDT, J \& SMITH, M. F. The Epicurean Inscription of Diogenes of Oinoanda: Ten Years of New Discoveries and Research. Bonn: Verlag Dr. Rudolf Habelt, 2014. Resenha de: GORDON, P. The Epicurean Inscription of Diogenes of Oinoanda: Ten Years of New Discoveries and Research. Disponível em: <http://bmcr.brynmawr.edu/2016/2016-07-38.html>. Acesso em: 20 ago. 2019.

MARX, K. Diferença entre as Filosofias da Natureza de Demócrito e Epicuro. Trad. Edson Bini, Armandina Venâncio. São Paulo: Global, 1979.

MORAES, J. Q. de. A Linha Reta e o Infinito na Refundação Epicureana do Atomismo. In: Cadernos de História e Filosofia da Ciência, Campinas, v. 14, n. 1, p. 7-47, 2004. Disponível em: <https://www.cle.unicamp.br/eprints/index.php/cadernos/article/view/729 >. Acesso em: 23 jan. 2017.

PARENTE, M. I. Opere di Epicuro. Torino: Unione Tipografico-Editrice Torinese, 1974.

PLATÃO. Timeu-Crítias. Trad. Rodolfo Lopes. Coimbra: Centro de Estudos Clássicos e Humanísticos, 2011.

ROSTOVTZEFF, M. História da Grécia. Trad. Edmond Jorge. Rio de Janeiro. Zahar, 1983.

SEDLEY, D. A Escola, de Zenão a Ário Dídimo. In: INWOOD, B. (Org.). Os Estoicos. Trad. Raul Fiker. São Paulo: Odysseus, 2006.

\begin{tabular}{|l|l|l|l|l|}
\hline Q Povista Dialectus & Ano 9 & n. 16 & Janeiro-Abril 2020 & p. $11-37$ \\
\hline
\end{tabular}


SMITH, J. \& HAMMERSTAEDT, M.F. Diogenes of Oinoanda: The discoveries of 2008 (NF 142-167). In: Epigraphica Anatolica, v. 41, p. 1-37, 2008.

SPINELLI, M. Os Caminhos de Epicuro. São Paulo: Loyola, 2009.

TITO LUCRÉCIO CARO. Da Natureza. Trad. Agostinho da Silva. São Paulo: Abril Cultural, 1973. 